\title{
TINJAUAN TENTANG PARTISIPASI MASYARAKAT DALAM MENDUKUNG PEMBANGUNAN DI DESA SANGATTA UTARA KABUPATEN KUTAI TIMUR
}

Oleh :

\author{
Salasiah $^{1}$ dan Hasbiah ${ }^{2}$ \\ ${ }^{1}$ Mahasiswa Fakultas Ilmu Sosial dan Ilmu Politik \\ Universitas 17 Agustus 1945 Samarinda \\ ${ }^{2}$ Dosen Fakultas Ilmu Sosial dan Ilmu Politik \\ Universitas 17 Agustus 1945 Samarinda
}

\begin{abstract}
This research is based on community participation in participation in developing their village, both in mind participation, participation of personnel, participation of expertise, participation of goods and money participation.

The purpose of this study is to find out how the community participation in the implementation of regional development in the village of North Sangatta Kecamatan Sangatta North East Kutai Regency. Type of research or explanation used is descriptive qualitative used to describe research variables. Types of data used, observation interviews, and documentation.

With the implementation of research in North Sangatta village, Kecamatan Sangatta Utara, East Kutai Regency is expected to give an idea how community participation in the implementation of regional development so that the concept of participatory development that has been applied can be measured and can be used as a reference in subsequent research related to the substance of the discussion.

From the results of the research that has been carried out, it can be illustrated that the application of participatory development in the village of North Sangatta if referring to the musrenbang results that have been recorded in BAPPEDA of East Kutai Regency, the result obtained is that although in the planning phase the community still participates, but at the stage of implementation of community participation which is expected to exist, was not found at all, because at the stage of project implementation carried out by the winning contractor. However, if we refer to the development project implemented by the empowerment program running in the village of Sangata Utara, mainly funded from the village allocation fund, the research found that
\end{abstract}


the enthusiasm of the community to participate in every stage of development carried out from the planning, implementation, until the project evaluation phase is very high. This can be concluded in the implementation stage there are still many things that must be addressed.

Keywords: Community, Participation

\section{PENDAHULUAN}

\section{A. Latar Belakang}

Penyertaan masyarakat sebagai subjek pembangunan adalah suatu keniscaayaan dalam upaya mewujudkan tujuan pembangunan nasional. Ini berarti masyarakat diberi peluang untuk berperan aktif mulai dari perencanaan, pelaksanaan hingga evaluasi setiap tahap pembangunan yang diprogramkan. Terlebih apabila kita akan melakukan pendekatan pembangun dengan semangat lokalitas. Masyarakat lokal dengan pengetahuan serta pengalamannya menjadi modal yang sangat besar dalam melaksanakan pembangunan, karena masyarakat lokal-lah yang mengetahui apa permasalahan yang dihadapi serta potensi yang dimiliki oleh daerahnya. Masyarakat memiliki kedaulatan yang cukup luas untuk menentukan orientasi dan arah kebijakan pembangunan yang dikehendaki. Nilainilai kedaulatan selayaknya dibangun sebagai kebutuhan kolektif masyarakat dan bebas dari kepentingan individu dan atau golongan.

Perlunya keterlibatan masyarakat ini dianggap sangat penting, karena pembangunan yang terlalu menekankan peranan pemerintah birokrasi (bercirikan top down) mendapat kritikan tajam, dimana kurang peka terhadap kebutuhan lokal Korten (2000:87). Dari pada itu, pelaksanaan pembangunan yang mengutamakan masyarakat dalam pelaksanaan program-program pembangunan, berarti memberikan peluang seluas-luasnya kepada masyarakat untuk mengarahkan sumber daya, potensi, merencanakan serta membuat keputusan dan mengevaluasi kegiatan-kegiatan pembangunan yang akan mensejahterakan mereka, sehingga mereka berdaya.

Hasil penelitian W. Boyers tahun 1985 menyimpulkan bahwa legitimasi dan keberhasilan dari suatu program pembangunan dalam skala nasional bagi suatu negara berkembang, program yang dilakukan dengan memperhatikan situasi dilaksanakan dari bawah ke atas (bottom-up), dan program tersebut sesuai bagi rakyat, ketimbang dilakukan secara seragam (top-down) dengan program yang didominasi oleh pemerintah pusat.

Di Indonesia, rencana pembangunan secara nasional diberikan tempat central kepada pembangunan pedesaan. Hal ini disebabkan karena kurang lebih $75 \%$ penduduk Indonesia berdiam di pedesaan. Sehingga dengan 
demikian, upaya perencanaan pembangunan masyarakat pedesaan tidaklah lepas dari setiap program pembangunan nasional. Pembangunan desa sebagai bagian integral dari pembangunan nasional mempunyai arti strategis, karena desa secara keseluruhan merupakan basis atau landasan negara RI yang diukur dalam kancah pembangunan nasional, serta keterkaitan dengan kondisi-kondisi sosial masyarakat yang masih terbelakang merupakan tantangan bagi peningkatan kesejahteraan masyarakat yang adil dan merata.

Desa sebagai kesatuan masyarakat hukum terkecil yang memiliki batas-batas wilayah yang berwenang untuk mengatur dan mengurus kepentingan masyarakatnya berdasarkan asal-usul dan adat istiadat setempat yang diakui dan dihormati oleh negara. Pembangunan pedesaan selayaknya mengarah pada peningkatan kesejahteraan masyarakat pedesaan. Pembangunan pedesaan dapat dilihat pula sebagai upaya mempercepat pembangunan pedesaan melalui penyediaan sarana dan prasarana untuk memberdayakan masyarakat, dan upaya mempercepat pembangunan ekonomi daerah yang efektif dan kokoh. Pembangunan pedesaan bersifat multiaspek, oleh karena itu perlu keterkaitan dengan bidang sektor dan aspek di luar pedesaan, sehingga dapat menjadi pondasi yang kokoh bagi pembangunan nasional.

Kutai Timur merupakan salah satu kabupaten yang berada pada wilayah Provinsi Kalimantan Timur. Dalam menunjang kegiatan pembangunannya, maka visi dan misi yang harus dicapai adalah peningkatan kinerja pembangunan daerah. Oleh karena itulah, dalam menunjang visi dan misi tersebut, maka keterlibatan atau partisipasi dari masyarakat dalam proses pembangunan mulai dari perencanaan, pelaksanaan, sampai pada evaluasi hasil pembangunan sangat penting utamanya di tingkat desa. Terkait hal tersebut kabupaten Sidenreng Rappang telah mengeluarkan berbagai perangkat hukum, mulai dari Perda Kutim nomor 2 tahun 2004 tentang peraturan kewenangan desa, Perda Kutim nomor 7 tahun 2004 tentang peraturan desa dan keputusan kepala desa, Perda Kutim nomor 53 tahun 2004 tentang partisipasi masyarakat dalam proses kebijakan publik, Perda Kutim nomor 3 tahun 2007 tentang sumber pendapatan desa.

Namun jika kita melihat ke belakang, bahwa mulai dari tahap perencanaan pembangunan yang menggunakan pola berjenjang dari bawah ke atas (BottomUp) ternyata tidak banyak menjanjikan aspirasi murni warga desa/kelurahan didengar. Begitu pun halnya dalam pelaksanaan proyeknya yang masih menggunakan sistem tender, di mana tender yang dimaksud melibatkan para kontraktor sebagai pihak ketiga dalam pelaksanaan pembangunan daerah yang basisnya tentu berada di desa. Hal tersebut menunjukkan bahwa, ternyata keterlibatan masyarakat dalam proses pembangunan hanya selesai pada tahap perencanaan yang pada tahap itu pun masih banyak langkah-langkah yang belum terlaksana dengan baik, sehingga 
implementasi pola tersebut dapat dikritisi mengandung banyak kelemahan. Misalnya, partisipasi masyarakat selaku penerima manfaat sangat lemah, hasil dari berbagai forum koordinasi di tingkat lebih rendah (desa/Kelurahan) kadang tidak digubris oleh pemerintah yang lebih tinggi, mekanisme perencanaan mulai dari musrenbang desa/Kelurahan hanya bersifat mencatat daftar kebutuhan masyarakat ketimbang sebagai proses perencanaan yang partisipatif. Proses tersebut akhirnya menjadi proses birokratis yang sangat panjang dan lama, sehingga masyarakat tidak mendapat kepastian kapan kebutuhannya akan terwujud.

Bila demikian adanya, maka realita ini tentu saja dapat menghambat jalannya proses pembangunan yang melibatkan masyarakat di dalamnya (partisipatif). Padahal, sebagaimana yang telah dijelaskan di atas bahwa macetnya pembangunan partisipatif akan memunculkan pola-pola pembangunan yang tidak aspiratif.

Hal tersebut di atas kemudian memunculkan pertanyaan di Kabupaten Kutai Timur, khususnya di desa Sangatta Utara Kecamatan Sangatta Utara bahwa apakah partisisipasi masyarakat di dalam pelaksanaan pembangunan telah terlaksana dengan baik, di mana masyarakat tidak lagi menjadi objek pembangunan, akan tetapi telah menjadi subyek pembangunan. Dengan maksud bahwa partisipasi masyarakat dalam pelaksanaan pembangunan bukan hanya sekedar dilihat dari antusiasme masyarakat dalam menghadiri Musrenbang, akan tetapi, bagaimana kepentingan mereka telah direspon oleh pemerintah, serta bagaimana proses pelibatan mereka baik dalam tahap perencanaan sampai tahap pelaksanaan proyek pembangunannya. Karena antusiasme masyarakat kemudian lahir ketika substansi dari proses pembangunan itu telah tercipta.

\section{B. Permasalahan}

Berdasarkan latar belakang di atas, maka yang menjadi rumusan masalah dalam penelitian ini adalah : Bagaimana Partisipasi Masyarakat Dalam Pembangunan Di Desa Sangatta Utara Kecamatan Sangatta Utara Kabupaten Kutai Timur.

\section{METODE PENELITIAN}

Analisis data menurut (Sanapiah Faisal $(2000 ; 255)$ terdiri dari tiga alur kegiatan yaitu :

1. Reduksi data (data reduction) yang merupakan proses merangkum, mengiktisarkan atau menyeleksi data dari catatan lapangan yang kemudian dimasukkan dalam kategori tema yang mana, fokus atau konsen pada permasalahan yang mana sesuai dengan fokus penelitian. 
2. Penyajian data (data display) merupakan proses penyajian data kedalam sejumlah matrik yang sesuai yang berfungsi untuk memetakan data yang telah direduksi, juga untuk memudahkan mengkonstruksi ke dalam rangka, menuturkan, menyimpulkan dan menginterprestasikan data.

3. Menarik kesimpulan, yaitu membuat suatu kesimpulan sementara yang dapat dijadikan sebagai suatu pembekalan dalam melaksanakan penelitian untuk memberikan penafsiran dari data yang diperoleh terurama data yang berhubungan dengan fokus penelitian. Penarikan kesimpulan atau verifikasi dilakukan dengan longgar, tetap terbuka tetapi semakin lama semakin rinci, berdasarkan kesimpulan-kesimpulan data yang diperoleh dilapangandan mengakar dengan kokoh. Data yang diperoleh dilapangan, disajikan sedemikian rupa, kemudian dianalisia terhadap data tersebut untuk memperoleh hasil yang sebenarnya.

Apabila analisis yang digunakan adalah analisis kualitatif, maka analisis datanya akan lebih banyak menggunakan kata-kata, data-data yang berupa angka atau tabel guna menunjang kelengkapan data dan penelitian harus mampu mengembangkan analisa yang obyektif dengan nilai ilmiah yang tinggi.

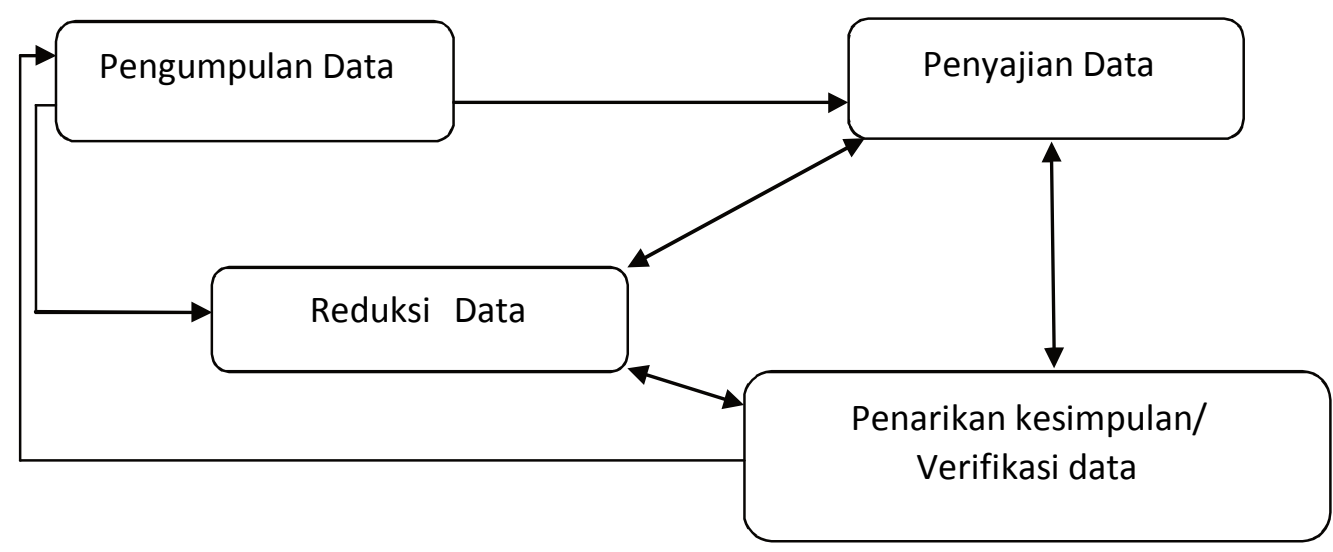

Miles dan Huberman(dalam Rachman, 2011: 175)

Gambar 2.1. Alur Proses Analisis Data

\section{HASIL PENELITIAN DAN PEMBAHASAN}

Dalam pelaksanaan proyek yang dilaksanakan oleh segenap masyarakat di desa Sangatta Utara Kecamatan Sangatta Utara, proyek yang akan dilaksanakan tidak langsung diputuskan secara sepihak saja oleh tim pelaksana kegiatannya ataupun oleh pemerintah desa setempat melainkan dengan melakukan penggalian gagasan yang mendalam dengan melibatkan masyarakat secara keseluruhan agar semua kebutuhan 
masyarakat dapat tertampung semua, seperti yang telah dikemukakan oleh Ketua BPD Sangatta Utara :

"Dalam penggalian usulan, digali dari setiap dusun, apakah di satu dusun itu dilakukan hanya sekali ataukah lebih dari sekali dengan titik lokasi yang berbeda, bergantung dari kondisi geografis dusun tersebut (susah dijangkau karena medannya yang sulit ataukah faktor lainnya) ini supaya semua kebutuhan masyarakat yang mendesak dapat tercover" (Ketua BPD Sangatta Utara, wawancara: 4 Maret 2019)

Demikian juga yang dikemukakan oleh salah seorang tokoh masyarakat desa Sangatta Utara:

"Pada proyek pengadaan fisik ini penggalian gagasannya dilaksanakan mulai tingkat dusun hingga tingkat desa" (Tokoh masyarakat, wawancara: 31 Februari 2019)

Ditambahkan lagi bahwa:

"Kegiatan pengadan fisik sekarag ini memang kegiatan pemberdayaan masyarakat, sehingga masyarakat memang harus terlibat" (Tokoh masyarakat, wawancara: 31 Februari 2019)

Informasi tersebut menunjukkan bahwa proyek yang dilaksanakan oleh pemerintah desa benar-benar merupakan proyek yang idenya digali dari masyarakat desa Sangatta Utara dan telah sesuai dengan apa yang dibutuhkan oleh masyarakat. Dari proses penggalian gagasan tersebut, maka lahirlah beberapa usulan yang akan mewakili kebutuhan masyarakat, yang selanjutnya akan diranking sesuai dengan skala kebutuhan masyarakat dan dimusya-warahkan dalam musyawarah di tingkat desa.

Dana Alokasi Desa yang merupakan dana yang salah satunya diperuntukkan untuk kegiatan fisik, yang dalam programnya harus mempunyai transparansi yang baik, serta mengupayakan keterlibatan penuh masyarakat desa di dalam proses pelaksanaannya. Oleh karena itu proyek yang telah didapatkan oleh desa Sangatta Utara, kemudian disosialisasikan kepada masyarakat untuk membahas langkah apa yang sebaiknya dilakukan agar proyek dapat terlaksana dengan baik dengan memperhatikan kualitas dari proyek tersebut.

Dalam pelaksanaan proyek secara teknis juga tidak dapat terlepas dari pemanfaatan sumber daya manusia dan sumber daya alam yang terdapat di desa bersangkutan. Hal ini dikecualikan jika sumber daya yang dimaksudkan tidak terdapat di desa, seperti yang dijelaskan oleh Kepala Desa Sangatta Utara : 
"Semua pekerja proyek adalah orang asli desa, misalnya bagi yang memiliki keahlian sebagai tukang batu, silahkan kerjakan yang bagian pemasangan batu, lagian tetap diberi upah kerja. Dan sebagai partisipasi mereka, maka upah yang mereka minta pun tidak seperti jika mereka bekerja biasanya" (Kepala Desa Sangatta Utara, wawancara : 5 April 2018)

Hal senada juga dikemukakan oleh Ketua BPD Sangatta Utara :

"Untuk masalah pengerjaan yang sifatnya membutuhkan keahlian, maka dicari pula masyarakat di desa ini yang betulu-betul ahli dalam bidang tersebut" (Ketua BPD Sangatta Utara, wawancara : 5 April 2019)

Dari penjelasan tersebut, dapat dipahami bahwa pelaksanaan pembangunan fisik ini memang menekankan pada pemberdayaan masyarakat dan tentunya hal tersebut tidak dapat dilepaskan dengan adanya sosialisasi yang dilakukan, karena tanpa adanya sosialisasi, maka kendati terdapat minat masyarakat dalam berpartisipasi akan tetap menyurutkan hal tersebut. Dengan adanya sosialisasi yang baik, maka informasi yang didapatkan dari sosialisasi akan dapat menjadi pemicu terhadap timbulnya partisipasi.

Dari penelitian di lapangan ditemukan bahwa di desa Sangatta Utara sifat gotong royong masyarakat masih tinggi, hanya saja bagaimana peran dari pemerintah desa dalam mengarahkannya dan mensosialisasikan kegiatan yang akan dilaksanakan, seperti yang dikemukakan oleh salah seorang tokoh masyarakat :

"Semangat gotong royong di desa Sangatta Utara ini Alhamdulillah masih sangat kental, dan mereka sangat bersemangat apabila mereka dipanggil untuk turut berpastisipasi dalam setiap kegiatan" (Tokoh pemuda desa Sangatta Utara, wawancara : 5 Appril 2019)

Berdasarkan hasil penelusuran informasi ditemukan bahwa di lokasi penelitian, perhatian pemerintah desa dalam mengarahkan masyarakat sangatlah baik serta dalam setiap kegiatan pembangunan yang akan dilaksanakan asalkan proyek tersebut jelas, pemerintah desa selalu melakukan sosialisasi yang baik, seperti yang di sampaikan salah seorang tokoh masyarakat bahwa :

"Setiap ada sesuatu yang akan dikerjakan, misalnya membicarakan masalah pembangunan, maka pemerintah desa selalu menyampaikan kepada masyarakat, mereka tak bertindak sendiri" (Tokoh masyarakat desa Sangatta Utara, wawancara : 5 April 2019) 
Pernyataan ini juga diperkuat oleh keterangan dari Ketua BPD Sangatta Utara:

"Saya juga salut kepada pemerintah desa Sangatta Utara, bahwa mereka benar-benar terlibat dalam memberikan sosialisasi kepada masyarakat. Misalnya, setiap kegiatan mereka selalu hadir dan di sanalah mereka member sosialisasi, sehingga tak adalagi istilah bahwa masyarakat tidak tahu" (Ketua BPD Sangatta Utara, wawancara : 8 April 2019)

Informasi tersebut menunjukkan bahwa dukungan pemerintah desa dalam setiap kegiatan pembangunan yang dilakukan di desa sangat baik begitu pula dengan penyambutan dari masyarakat yang begitu antusias dalam setiap kegiatan pembangunan.

Dengan adanya tersebut di Desa Sangatta Utara Kecamatan Sangatta Utara yang mengedepankan pemberdayaan masyarakat, maka tingkat antusiasme masyarakat desa dalam berpartisipasi dapat disandingkan, sehingga dapat melahirkan pembangunan desa sesuai dengan yang menjadi harapan, yakni pembangunan partisipatif yang sesuai dengan apa yang menjadi cita-cita the founding father negeri ini serta menjadi pembenaran tentang teori pembangunan yang sifatnya bottom up (dari bawah ke atas).

Meskipun demikian halnya, namun dalam pelaksanaan kegiatan tersebut masih belum dapat terlepas dari adanya hambatan. Seperti yang didapatkan pada lokasi penelitian di mana main set dari masyarakat mengenai proyek pembangunan yang masih selalu berfikir bahwa setiap proyek pembangunan merupakan hal yang mendatangkan untung bagi tim pelaksananya meski pun tidak demikian adanya, seperti informasi yang disampaikan oleh panitia pelaksana kegiatan fisik di desa Sangatta Utara bahwa :

"Hanya saja pada kegiatan ini adalah masyarakat kadang mengira bahwa pengerjaan kegiatan fisik ini seperti pengerjaan proyek yang biasanya, dalam artian bahwa mereka kadang berpikir bahwa paniti pelaksana pasti mendapat banyak untung, misalnya kalau ada sisa dana pasti kami yang akan mengambil sisa dana tersebut, padahalkan yang kami dapat hanyalah upah operasional saja" (Ketua Tim Pelaksana Kegiatan fisik desa Sangatta Utara, wawancara : 10 April 2019)

Munculnya pembahasan proyek pembangunan Dana Alokasi Desa dalam skripsi ini dikarenakan oleh proyek pembangunan yang dikontrol oleh Badan Perencanaan Pembangunan Daerah (BAPPEDA) melalui mekanisme penggalian gagasan Musyawarah Perencanaan Pembangunan (MUSRENBANG) ternyata belum berjalan sesuai dengan yang telah dikonsepkan dan masih terdapat banyak celah terutama dalam 
hal pelaksanaan proyeknya yang masih menggunakan pihak ketiga dalam hal ini kontraktor, sehingga mustahil untuk menghadirkan partisipasi masyarakat di dalamnya, seperti yang diungkapkan oleh Kepala Desa Sangatta Utara bahwa:

"Dalam proyek pembangunan dari pemerintah daerah yang ditangani oleh BAPPEDA dengan menggunakan pihak ke-3, jangankan partisipasi masyarakat dalam bentuk, tenaga, keahlian, barang, atau uang, partisipasi masyarakat dalam bentuk pikiran pun tidak ada. Sangat tidak menarik, hanya saja masyarakat tidak dapat menolak. Berbeda dengan program pembangunan yang ditangani oleh panitia pelaksana yang ada di desa ini, masyarakat sangat antusias dalam pelaksanaan program/proyek pembangunannya, karena betul-betul melibatkan masyarakat, mulai dari mengumpulkan masyarakat dan membicarakan bersama mengenai program/proyek yang akan dilaksanaan, sehingga masyarakat betul-betul berpartisipasi, mulai dari pikiran, tenaga, keahlian, barang kalau dibutuhkan, bahkan uang sekalipun" (Kepala Desa Sangatta Utara, wawancara : 20 Maret 2019)

Demikian pula yang diungkapkan oleh salah seorang tokoh masyarakat bahwa :

"Kalau untuk proyek pembangunan yang diturunkan dari hasil Musrenbang yang kemudian pelaksanaannya dikerjakan oleh kontraktor memang partisipasi masyarakat tidak ada" (Tokoh masyarakat Desa Sangatta Utara, wawancara : 18 Maret 2019)

Dari informasi tersebut dapat disimpulkan bahwa jika proyek dari hasil MUSRENBANG yang akan dijadikan sebagai unit analisis untuk mengetahui tingkat partisipasi masyarakat, maka akan menjadi hal yang mustahil dilakukan, sehingga dengan demikian mesti ada opsi lain yang dapat dijadikan sebagai alternatif pengganti, yaitu dengan menjadikan salah satu proyek dari Dana Alokasi Desa (DAD) yang diperolah desa Sangatta Utara sebagai tolak ukurnya, dalam hal ini proyek yang dianggarkan untuk tahun 2017, yakni pembangunan Pos Pelayanan Terpadu (POSYANDU) yang selanjutnya secara kualitatif ditelusuri melalui dimensi-dimensi sebagaimana dikemukakan oleh Davis yang dikutip oleh Sastropoetro (2000:16), terdiri atas: partisipasi pikiran; partisipasi tenaga; partisipasi keahlian; partisipasi barang; dan partisipasi uang.

\section{A. Partisipasi Pikiran}

Mengajak masyarakat untuk terlibat dalam pekerjaan proyek bukanlah hal mudah. Hal ini karena, masyarakat selalu beranggapan bahwa proyek-proyek yang ada dilingkungan pemerintahan desa 
merupakan proyek pemerintah yang pada dasarnya mempunyai anggaran yang cukup untuk melaksanakan proyek-proyek fisik tersebut. Oleh karena itu, setiap orang yang terlibat dalam pekerjaan proyek-proyek itu harus mendapat upah. Tidak terkecuali proyek pembangunan POSYANDU.

ini wajar karena unsur partisipasi menurut Keith Davis salah satunya adalah keterlibatan mental dan perasaan, lebih dari pada tersebut atau hanya keterlibatan secara jasmaniah. Pada awalnya, masyarakat Desa sangatta utara cenderung tidak mau berpartisipasi. Namun setelah mendapat pengarahan dari Kepala Desa beserta aparatnya, juga tokoh-tokoh maka masyarakat mulai memahami dan sadar akan tugas dan tanggung jawabnya dalam proses pelaksanaan proyek POSYANDU.

Partisipasi masyarakat dimaksud merupakan wujud kerjasama antara pemerintah desa dengan warga desanya. Dijelaskan oleh Kepala Desa Sangatta Utara bahwa :

"Memperjuangkan pengadaan POSYANDU di Desa Sangatta Utara bukanlah upaya baru. Masyarakat Desa Sangatta Utara sangat membutuhkan adanya Pos Pelayanan Terpadu - Mandiri Pedesaan. Akhirnya upaya tersebut baru terealisasi pada tahun 2017. Keputusan tentang pengadaan POSYANDU bukanlah merupakan keputusan Kepala Desa dan aparatnya saja melainkan merupakan hasil keputusan Musyawarah Desa yang pada dasarnya merupakan masukan dari warga desa utamanya tokoh-tokoh masyarakat" (Kades Sangatta Utara, wawancara : 5April 2019).

Ungkapan Kepala Desa tersebut menunjukkan bahwa masyarakat utamanya para tokohnya senantiasa memikirkan tentang kebutuhan bersama warga desa mereka yang selanjutnya disampaikan kepada pimpinan mereka, yaitu Kepala Desa untuk diperjuangkan pada tingkat kecamatan dan kabupaten. Keinginan yang disampaikan oleh tokoh-tokoh masyarakat tersebut, tentu bukan juga merupakan pemikiran dan keinginan mereka sendiri, akan tetapi itu juga merupakan keinginan warga desa secara keseluruhan. Kepala Desa Sangatta Utara, juga menginformasikan, bahwa :

"Secara jujur harus diakui bahwa masih terdapat sebagian warga desa kami yang meskipun telah disosialisakan dan bahkan secara langsung diajak untuk ikut serta berpartisipasi, namun mereka tetap berpendirian bahwa proyek kegiatan pengadaan fisik yang dalam hal ini adalah pembangunan POSYANDU telah ada anggarannya sehingga bila mereka bekerja harus mendapat upah sebagaimana lazimnya" (Kades Sangatta Utara, wawancara: 5 April 2019) 
Selanjutnya, Kepala Desa menuturkan bahwa:

"Di proyek ini masyarakat dilibatkan untuk membicarakan bagaimana suatu proyek pembangunan dilaksanakan, sehingga banyak ide yang dapat memperlancar jalannya proyek dan juga dapat memaksimalkan penggunaan dana, ketika misalnya proyek membutuhkan sesuatu justru masyarakat yang menyumbangkannya." (Kades Sangatta Utara, wawancara: 5 April 2019)

Penjelasan Kepala Desa tersebut menunjukkan bahwa masih terdapat warganya yang lebih mementingkan dirinya sendiri dan belum tergerak hatinya untuk memikirkan kepentingan bersama. Mereka belum menyadari bahwa pada dasarnya terpenuhi kepentingan bersama sesungguhnya telah terpenuhi juga kepentingan pribadi mereka. Misalnya, melalui POSYANDU maka kebutuhan dan kepentingan kesehatan diri dan keluarga mereka telah terpenuhi. Secara lebih umum, dikemukakan oleh Ketua BPD Sangatta Utara, bahwa:

"Dalam proyek pembangunan dari pemerintah daerah yang ditangani oleh BAPPEDA dengan menggunakan pihak ke-3, jangankan partisipasi masyarakat dalam bentuk, tenaga, keahlian, barang, atau uang, partisipasi masyarakat dalam bentuk pikiran pun tidak ada. Sangat tidak menarik, hanya saja masyarakat tidak dapat menolak. Berbeda dengan program pembangunan yang ditangani panitia pelaksana desa yang ada di desa ini, masyarakat sangat antusias dalam pelaksanaan proyek pembangunannya, karena betul-betul melibatkan masyarakat, mulai dari mengumpulkan masyarakat dan membicarakan bersama mengenai program/proyek yang akan dilaksanaan, sehingga masyarakat betul-betul berpartisipasi, mulai dari pikiran, tenaga, keahlian, barang kalau dibutuhkan, bahkan uang sekalipun." (Ketua BPD Sangatta Utara, wawancara : 8 April 2019)

Ungkapan Kepala BPD tersebut mengindikasikan bahwa partisipasi masyarakat Desa Sangatta Utara hanya bisa ditelusuri melalui proyek-proyek Kegiatan Pembangunan Fisik, karena proyek-proyek yang ditangani oleh pihak ketiga merupakan proyek-proyek tender yang dikelola langsung oleh pemenangnya. Dan biasanya, proyek-proyek tersebut (misalnya jalan, jembatan dan lain sebagainya) yang mana membutuhkan dana yang besar dan teknologi yang membutuhkan skill yang memadai.

Selain partisipasi dalam bentuk pemikiran yang disampaikan sebagai masukan dalam rangka memperoleh bantuan proyek, sebagian masyarakat juga memberikan masukan pikiran-pikiran teknis dalam 
rangka pelaksanaan pisik bangunan POSYANDU. Antara lain partisipasi (pikiran) dengan mengusulkan agar dana sisa dari bangunan tersebut dimanfaatkan untuk membangun pagar gedung POSYANDU. Masukan ini selanjutnya diterima oleh Kepala Desa dan selanjutnya dibangunlah pagar di bagian depan dan samping bangunan

POSYANDU. Hal tersebut disampaikan oleh salah seorang tokoh masyarakat Desa Sangatta Utara, bahwa:

"Pada saat bangunan POSYANDU dikerjakan, banyak anggota masyarakat yang terlibat di dalamnya, tanpa dibayar. Mereka datang bekerja karena menyadari bahwa POSYANDU merupakan kebutuhan bersama dan pasti akan memberikan pelayanan kepada semua masyarakat tanpa membedakan antara warga yang satu dengan warga yang lainnya. Mereka juga memberikan petunjuk-petunjuk teknis sehingga POSYANDU dapat terselesaikan sebagaimana diharapkan."

(Tokoh Masyarakat, wawancara: 2 Maret 2019).

\section{B. Partisipasi Tenaga}

Selain partisipasi dalam bentuk pemikiran, tenaga merupakan salah satu bentuk partisipasi dari masyarakat desa yang sangat potensial diarahkan dalam proses pembangunan desa, khususnya dalam pengerjaan proyek-proyek fisik. Sejarah telah mencatat bahwa masyarakat Indonesia, terutama mereka yang tinggal di pedesaan dapat menyelesaikan berabagai pekerjaan atas dasar gotong-rotong atau swadaya. Dengan dana yang terbatas, mereka mampu dan berhasil menyelesaikan pekerjaan-pekerjaan fisik yang mahal, misalnya masjid, balai desa, bahkan sekolah dan lain sebagainya. Kenyataan seperti ini menunjukkan bahwa mengarahkan masyarakat desa untuk berpartisipasi dalam pembangunan desanya tidak semata-mata tergantung pada aspek anggaran. Kepemimpinan juga merupakan salah satu faktor yang ikut menentukan tingkat partisipasi masyarakat desa. Artinya, Kepala Desa beserta aparatnya harus mampu menjalankan roda pemerintahan desa secara jujur, transparan, akuntabel dan religius. Dengan demikian mayarakat yang dipimpin akan cenderung untuk mengikuti arahan pemerintah desa guna menyumbangkan tenaga mereka dalam pelaksanaan proyek-proyek pembangunan di desanya.

Seperti yang telah dikemukakan oleh Bapak Pu'Bari bahwa banyak anggota masyarakat yang terlibat dalam pengerjaan gedung POSYANDU atas dasar kesadaran bahwa keberadaan POSYANDU sangat bermanfaat bagi warga Desa Sangatta Utara. Olehnya itu, meskipun tersedia anggaran untuk pembangunan tersebut, namun mereka tidak berharap untuk dibayar. Di lain pihak, sebagaimana 
dikemukakan juga oleh salah seorang tokoh masyarakat bahwa pada dasarnya semua masyarakat Desa Sangatta Utara ingin berpartisipasi dalam pelaksanaan proyek-proyek pembangunan fisik, terutama dalam bentuk partisipasi tenaga.

Memang harus diakui bahwa masyarakat Desa Sangatta Utara dapat dikatakan cukup partisipatif dalam pelaksanaan proyek-proyek pembangunan desanya. Akan tetapi harus diakui pula bahwa masih banyak diantara mereka yang harus mencari nafkah untuk menghidupi keluarganya sehari-hari. Demikian antara lain dikemukakan oleh seorang Tokoh Masyarakat, bahwa :

"Banyak warga yang tidak sempat berpartisipasi karena memang di Desa Sangatta Utara masih banyak warga yang kalau mereka tidak bekerja dalam beberapa hari, maka mereka tak akan bisa memenuhi kebutuhan sandang pangan mereka, dan mata pencaharian yang paling dominan adalah berdagang, tenaga buruh kebun sawit dan tenaga buruh kasar dan kadang itu di luar daerah". (Tokoh Masyarakat, wawancara: 5 April 2019).

Informasi tersebut memperlihatkakn bahwa partisipasi seseorang di dalam pelaksanaan kegiatan tertentu bukanlah merupakan paksaan, akan tetapi kerelaan untuk terlibat. Kerelaan itu sendiri muncul dari kesadaran bahwa keterlibatan mereka dalam bentuk partisipasi tenaga itu adalah suatu upaya untuk mewujudkan kemaslahatan bagi orang banyak. Seperti yang di kemukakan oleh kepala desa, bahwa :

"Masyarakat mau ikut berpartisipasi Karena mereka berpikir selain mereka ingin melihat pembangunan di daerahnya baik juga mereka berpikir bahwa hal tersebut juga bermanfaat bagi diri mereka" (Kepala Desa Sangatta Utara, wawancara: 5 April 2019).

\section{Partisipasi Keahlian}

Menyelesaikan suatu pekerjaan secara efektif dan efisien serta berkualitas sangat ditentukan oleh tingkat keahlian (skill) yang dimiliki oleh para pekerjanya. Keahlian tersebut juga harus ditunjang pula dengan motif dan kondisi kejiwaan dari para pekerja pada saat mereka bekerja. Hal ini penting dikemukakan mengingat partisipasi adalah keterlibatan atas dasar kerelaan yang akan mewujudkan hasil sebagaimana yang diharapkan Dikemukakan oleh Ketua BPD Sangatta Utara, bahwa :

"Bila dibandingkan proyek-proyek pembangunan di desa ini yang dilaksanakan oleh pihak ke-3 dengan proyek pembangunan yang ditangani oleh panitia pelaksana desa yang melibatkan masyarakat, 
akan sangat berbeda. Proyek yang dilaksanakan oleh pihak ke-3 sudah mulai rusak meski baru beberapa lama selesai pengerjaannya sedangkan yang dilaksanakan oleh panitia pelaksana desa kualitasnya lebih bagus, karena memang melibatkan tukang terbaik di desa ini yang juga turut berswadaya". (Ketua BPD Sangatta Utara, wawancara: 8 April 2019)

Informasi ini mengindikasikan bahwa: (a) terdapat partisipasi masyarakat dalam bentuk keahlian; (b) tanggung jawab terhadap kualitas hasil, lebih tinggi pada proyek kegiatan pembangunan fisik dibandingkan dengan hasil yang ditunjukkan oleh proyek-proyek yang ditangani oleh pihak ke-3; dan (c) pemeliharaan terhadap proyek yag di tangani oleh panitia desa lebih baik dari pada pemeliharaan terhadap hasil-hasil proyek yang ditangani oleh pihak ketiga. Hal ini dapat dimaklumi, karena proyek kali ini oleh masyarakat Desa Sangatta Utara dianggap sebagai milik sendiri, sedangkan proyek yang ditangani pihak ke-3 dianggap sebagai milik negara atau daerah yang harus dijaga dan dirawat oleh negara atau daerah. Sesuai yang dikemukakan oleh kepala desa sangatta utara, bahwa :

"Semua pekerja proyek adalah orang asli desa, misalnya bagi yang memiliki keahlian sebagai tukang batu, silahkan kerjakan yang bagian pemasangan batu, lagian tetap diberi upah kerja. Dan sebagai partisipasi mereka, maka upah yang mereka minta pun tidak seperti jika mereka bekerja biasanya". (Kepala Desa Sangatta Utara, wawancara: 5 Aapril 2019)

Ungkapan itu menunjukkan bahwa kerelaan masyarakat untuk menyumbangkan keahlian mereka dalam pembangunan desanya adalah cukup tinggi. Mereka tetap bekerja dengan baik, meskipun upah yang mereka terima seadanya saja. Artinya upah bukanlah faktor utama dalam berpartisipasi, melainkan kesediaan mereka untuk bekerja sama dalam rangka mewujudkan tujuan bersama. Sebagai pimpinan, maka seyogyanya Kepala Desa Sangatta Utara beserta jajarannya melihat potensi keahlian dan kerelaan bekerja ini sebagai suatu kekuatan yang dapat diorganisir dan dimobilisasi secara efektif sehingga dapat bermanfaat bagi mereka dalam rangka memperoleh pendapatan yang lebih baik. Dikemukakan pula oleh Tokoh Masyarakat, bahwa :

"Di kecamatan Sangatta Utara khususnya di Desa Sangatta Utara, partisipasi masyarakat yang dapat dilihat adalah dominan partisipasi tenaga dan juga partisipasi keahlian dari masyarakat yang 
memiliki keahlian misalnya sebagai tukang batu dan tukang kayu, dan keahlian lainnya, yang bila diperlukan maka mereka akan siap untuk bekerja sebagaimana yang diharapkan". (Tokoh Masyarakat, Desa Sangatta Utara, wawancara: 4 April 2019).

Informasi dari Kepala Desa Sangatta Utara ini menunjukkan bahwa warga desa Sangatta Utarak hususnya kaum laki-laki yang berada di Desa Sangatta Utara banyak yang memiliki keahlian sebagai tukang batu, tukang kayu dan keterampilan teknis lainnya yang mereka peroleh dari pengalaman langsung di lapangan. Banyak diantara mereka tidak memiliki tingkat pengetahuan yang memadai. Dengan keahlian yang mereka miliki, dapat dimanfaatkan dan diarahkan secara optimal dalam rangka pengerjaan proyek-proyek pembangunan fisik didesa sangatta utara dimasa yang akan datang.

\section{Partisipasi Barang}

Barang yang dimaksudkan dalam skripsi ini adalah barang-barang yang dimiliki oleh warga desa yang secara sukarela disumbangkan kepada desa dalam rangka pelaksanaan proyek-proyek kegiatan fisik. Seperti yang telah dikemukakan bahwa proyek pembangunan fisik POSYANDU memiliki dana sebesar Rp 63.119.000,00 yang bersumber dari Anggaran Pendapatan dan Belanja Negara (APBN). Pada pertemuan Desa, oleh Kepala Desa Sangatta Utara (hasil wawancara: 29 Maret 2017) menyampaikan secara transparan jumlah tersebut. Beliau menyampaikan bahwa untuk pengadaan POSYANDU yang memadai, tentunya dana tersebut belumlah cukup. Olehnya itu, diharapkan kesediaan warga untuk dapat menyumbangkan bahan-bahan tertentu yang dibutuhkan dalam rangka pembangunan fisik POSYANDU tersebut. Himbauan ini ternyata mendapat sambutan positif dari beberapa warga dan tokoh masyarakat. Sambutan positif dimaksud adalah pemberian secara sukarela beberapa bahan (kayu, paku, pasir dan lain-lain) yang dibutuhkan pada saat dibutuhkan dalam pengerjaan POSYANDU.

Dari bantuan-bantuan dimaksud maka pengeluaran pembangunan pisik POSYANDU dapat ditekan sehingga ada sisa Rp 5.663.355,00 yang selanjutnya digunakan untuk pengadaan pagar di bagian depan dan bagian samping POSYANDU. Dikemukakan oleh Ketua Tim Pelaksana Kegiatan, bahwa :

"Partisipasi masyarakat dalam bentuk barang, misalnya untuk proyek 2010, yakni pembangunan Posyandu, jadi tanah yang digunakan sebagai lokasinya adalah hasil dari swadaya masyarakat dalam bentuk barang, contohnya lagi untuk proyek 2009, yakni perintisan jalanan, 
itu juga diswadayakan dan tanah yang digunakan adalah tanah yang dihibahkan dari masyarakat yang panjangnya kurang lebih $350 \mathrm{~m}$, selain itu alat-alat yang digunakan pun adalah hasil dari partisipasi masyarakat". (Ketua Tim Pelaksana Kegiatan, wawancara : 8 April 2019)

Informasi ini kiranya secara jelas memperlihatkan bahwa masyarakat Desa Sangatta Utara memiliki kesadaran dan kerelaan yang cukup memadai dalam rangka pembangunan desa mereka. Dipandang dari sudut ekonomi, sesungguhnya mereka bukanlah orang-orang yang memiliki kekayaan yang berlebihan, sehingga sebagian dari harta mereka itu disumbangkan kepada desa. Akan tetapi, meskipun kehidupan mereka masih dalam taraf sederhana, mereka tetap rela untuk menyumbangkan sebagain dari miliki mereka untuk kepentingan pembangunan desa khususnya pembangunan POSYANDU pada tahun 2019.

Dikemukakan oleh Tokoh Masyarakat, bahwa:

"Kalau dalam bentuk barang itu disediakan oleh tim pelaksana desa, begitu pula dengan dananya yang memang semuanya harus dihabiskan untuk pendanaan pembanguan tanpa adanya penyelewengan jika memang nantinya ada dana yang tersisa, karena semuanya harus dipertanggung jawabkan. Malahan dana yang tersisa dirembukkan lagi dengan masyarakat, bahwa sisa dana tersebut mau dipakai untuk membiayai pembangunan yang mana lagi”, yang kemudian disepakati adalah untuk pembangunan pagar POSYANDU. (Tokoh masyarakat, wawancara : 4 April 2019)

Selanjutnya diinformasikan juga oleh seorang tokoh masyarakat, bahwa:

"Mengenai bahan proyek, itu disediakan oleh PNPM, hanya pengerjaannya yang di kerjakan oleh masyarakat, dan pengerjaannya tetap diawasi oleh aparat desa, tim yang bertanggungjawab dan masyarakat sendiri". Namun dalam pelaksanaannya, ada bantuan bahan-bahan tertentu dari anggota masyarakat yang kebetuan memiliki bahan yang dibutuhkan. Bahan-bahan tersebut diberikan secara sukarela tanpa paksaan dari pihak lain"(Tokoh Masyarakat, Bpk. Pu'Bari), wawancara: 31 Maret 2018).

Informasi ini semakin memperkuat fakta bahwa masyarakat Desa Sangatta Utara cukup partisipatif dalam rangka pelaksanaan proyek-proyek yang diberikan pemerintah kepada desa sebagai sarana pemenuhan kebutuhan masyarakat Desa secara keseluruhan. 


\section{E. Partisipasi Uang}

Diinformasikan oleh semua informan bahwa tidak terdapat partisipasi masyarakat Desa sanggatta utara dalam bentuk uang pada saat pembangunan selama kurang lebih empat bulan dilaksanakan. Kalaupun ada, hal itu diwujudkan dalam bentuk rokok dan minuman seperti kopi, sirup dan lainnya untuk konsumsi bagi masyarakat yang turut terlibat dalam pengerjaan proyek. Selain itu, juga karena memang proyek itu sudah memiliki anggaran dana yang cukup yang dikelola dengan baik oleh Tim Pelaksana Kegiatannya dan juga berkat bantuan atau dalam artian partisipasi masyarakat dalam bentuk sumbangsi tenaga dan keahlian yang jika menggunakan pekerja sewa akan memakan biaya, sehingga dana yang di anggarkan akan terhemat dan dapat digunakan lagi untuk kebutuhan pembangunan lainya. Hal ini sesuai dengan apa yang dikemukankan oleh Tim Pelaksana Kegiatan Desa Sangatta Utara, bahwa :

"Untuk partisipasi masyarakat dalam bentuk uang, selama ini belum pernah, Karena dana yang dianggarkan dari kegiatan inipun Alhamdulillah belum pernah kurang, malahan kadang memiliki sisa dari pengerjaan satu proyek yang dapat dijadikan revisi untuk proyek lain" (Ketua Tim Pelaksana Kegiatan pembangunan fisik Desa Sangatta Utara, wawancara : 10 April 2019).

Berdasarkan hasil wawancara di atas dapat disimpulkan bahwa dengan adanya sisa dana dari pelaksanaan proyek posyandu, maka dapat dijadikan sebagai indikator bahwa tingkat partisipasi masyarakat di desa Sangatta Utara Kecamatan Sangatta Utara sangatlah baik, sebagaimana yang salah satu alasan dari pentingnya partisipasi dalam kegiatan yang dikemukakan oleh Dr. Lastaire White dalam Sastropoetro (2000), yakni dengan partisipasi dari masyarakat, maka hasil kerja yang dicapai akan lebih banyak dibandingkan pengerjaannya dilakukan tanpa melibatkan masyarakat.

\section{A. Kesimpulan}

\section{PENUTUP}

1. Meskipun masih terdapat hambatan-hambatan kecil dalam membangun dan mengarahkan partisipasi masyarakat Desa Sangatta Utara, namun secara keseluruhan dapat dikatakan bahwa tingkat partisipasi masyarakat desa tersebut telah cukup memadai dalam rangka pelaksanaan proyek pengerjaan fisik di desa mereka. 
2. Dari lima jenis partisipasi yang dikaji, ternyata bentuk partisipasi tenaga memiliki sumbangan yang sangat signifikan dalam pengerjaan proyek kegiatan pengadaan fisik khususnya pembangunan POSYANDU pada tahun 2017.

3. Kepala Desa Sangatta Utara beserta aparatnya cukup aktif dan berhasil menjalankan fungsi dan perannya dalam mendorong dan mengarahkan partisipasi masyarakanya sehingga cukup berhasil dalam menyelesaikan salah satu proyek yang dikucurkan oleh pemerintah yaitu POSYANDU sebagaimana diharapkan oleh masyarakat desanya.

\section{B. Saran}

1. Diharapkan agar Kepala Desa dan aparatnya semakin gigih dalam berupaya memperjuangkan aspirasi masyarakat Desa Sangatta Utara guna mendapatkan proyek-proyek yang lain dilain waktu yang sesuai skala prioritas kebutuhan masyarakat desanya.

2. Agar Kepala Desa beserta jajarannya semakin menjalin hubungan yang baik dengan tokoh-tokoh masyarakat dan dengan masyarakat desa secara keseluruhan sehingga pertemuan-pertemuan yang mereka selenggarakan di masa yang akan datang dapat melahirkan gagasan-gagasan dan keputusankeputusan yang lebih baik guna menyukseskan setiap program dan proyek yang telah berhasil diperjuangkan oleh Kepala Desa.

3. Agar Kepala Desa dan aparatnya serta tokoh-tokoh masyarakat Desa Sangatta Utara senantiasa bersinergi menjadi teladan bagi masyarakat dalam memelihara dan merawat hasil-hasil pembangunan yang dicapai di Desa Sangatta Utara.

\section{BIBLIOGRAFI}

Abe, Alexander, 2002, Perencanaan Daerah Partisipatif, Penerbit Pondok Edukasi, Solo.

Adi, Isbandi Rukminto, 2001, Pemberdayaan, Pengembangan Masyarakat dan Intervensi Komunitas, Lembaga Penelitian FE-UI, Jakarta.

Adisasmita, R. 2006. Pembangunan Pedesaan Dan Perkotaan Yogyakarta: Graha Ilmu

Arif, Syaiful. 2006. Reformasi Birokrasi dan Demokratisasi Kebijaka. Malang: Averroes Cipta.

Arikunto, Suharsimi. 1993. Prosedur Penelitian Suatu Pendekatan Praktek. Jakarta: Rineka Cipta. 
Arsyad, Lincoln. 2002. Pengantar Perencanaan dan Pembangunan Ekonomi Daerah. Yogyakarta: BPFE.

Conyers, Diana. 2000. "An Introduction to Social Planning in The Third World". By Jhon Wiley \& Sons Ltd. 2001. Terjemahan Drs. Susetiawan. SU: "Perencanaan Sosial di Dunia Ketiga: Suatu Pengantar”. Yogyakarta: Gadjah Mada University Press.

Hasibuan, Malayu, S.P.Drs, 2000, Manajemen: Dasar, Pengertian dan Masalah, CV. Haju Masagung, Jakarta.

Kunarjo, 2002, Perencanaan dan Pengendalian Program Pembangunan, Universitas Indonesia UI Press, Jakarta.

Moleong, Lexy, 2001, Metodologi Penelitian Kualitatif, PT. Remaja Rosada Karya, Bandung.

Mubiyarto, 2000, Pembangunan Pedesaan, P3PK UGM, Yogyakarta.

Mikkelsen, Britha, 2006, Metode Penelitian Partisipatoris dan Upaya-upaya Pemberdayaan, Yayasan Obor Indonesia, Jakarta.

Michael, Todaro, 2000, Pembangunan ekonomi di dunia Ketiga, Erlangga, Jakarta.

Muhadjir, H. Noeng, 2000, Metodologi Penelitian Kualitatif, Rakesarasin, Yogyakarta.

Milles, MB \& Hubberman, AM, (2002) Analisis Data Kualitatif, Terjemahan oleh Tjetjep Rohidi dan mulyarto, UI Percetakan, Jakarta.

Moelyarto, Tjokrowinoto, 2001, Restrukturisasi Ekonomi dan Birokrasi, Kreasi Wacana, Yogyakarta.

Riyadi dan Bratakusumah, D.S, 2004, Perencanaan Pembangunan Daerah, PT. Gramedia Pustaka Utama, Jakarta.

ReksoPutranto, Soemadi, 2002, Manajemen Proyek Pemberdayaan, Lembaga Penerbitan FE-UI, Jakarta.

Siagian, Sondang P, 2001, Administrasi Pembangunan, Gunung Agung, Jakarta.

Singarimbun, Masri dan sofyan Effendi, 2002, Metode Penelitian Survey, Suntingan LP3ES, Jakarta.

Supriatna, Tjahya. 2000. Strategi Pembangunan dan Kemiskinan. Jakarta: Rineka Cipta.

Sugiono. 2004. Memahami Penelitian Kualitatif. Bandung: Alfabeta. 
Suryono, Agus. 2001. Teori dan Isu Pembangunan. Malang:

Universitas Malang Press.

Tjokroamidjojo, Bintoro, 2000, manajemen Pembangunan, Gunung Agung, Jakarta.

\section{Media Internet}

Aristo, D.A. 2004. Rejuvinasi Peran Perencana dalam Menghadapi Era Partispatif, "Sebuah Tahapan Awal dalam Pembentukan Kultur Masyarakat Partisipatif”. Disampaikan dalam: Seminar Tahunan ASPI (Asosiasi Sekolah Perencana Indonesia) Universitas Brawijaya, Malang. Teknik Planologi ITB. http://www.mirror.depsos.go.id 